\title{
EVALUATION OF INTERSECTORAL PARTNERSHIPS FOR MENTAL HEALTHCARE IN THE BRAZILIAN FAMILY HEALTH STRATEGY
}

\author{
Agnes Olschowsky, ${ }_{1}$ Christine Wetzel, ${ }^{2}$ Jacob Schneider Fernando, ${ }^{3}$ Leandro Barbosa de Pinho, ${ }^{4}$ Marcio \\ Wagner Camatta ${ }^{5}$
}

\begin{abstract}
${ }^{1}$ Ph.D. in Nursing. Professor at the School of Nursing and the Graduate Program in Nursing of the Universidade Federal do Rio Grande do Sul (UFRGS). Porto Alegre, Rio Grande do Sul, Brazil. E-mail: agnes@enf.ufrgs.br

${ }^{2}$ Ph.D. in Psychiatric Nursing. Adjunct Professor at the School of Nursing of UFRGS. Porto Alegre, Rio Grande do Sul, Brazil. E-mail: cwetzel@ibest.com.br

${ }^{3}$ Ph.D. in Nursing. Adjunct Professor at the School of Nursing and the Graduate Program in Nursing of the UFRGS. Porto Alegre, Rio Grande do Sul, Brazil. E-mail: jaco_schneider@uol.com.br

${ }^{4}$ Ph.D. in Psychiatric Nursing. Adjunct Professor at the School of Nursing and the Graduate Program in Nursing of the UFRGS. Porto Alegre, Rio Grande do Sul, Brazil. E-mail: lbpinho@uol.com.br

${ }^{5}$ Ph.D. in Nursing. Adjunct Professor at the Universidade Federal de Ciências da Saúde de Porto Alegre. Porto Alegre, Rio Grande do Sul, Brazil. E-mail: mcamatta@gmail.com
\end{abstract}

\begin{abstract}
The aim of this study was to evaluate intersectoral partnerships for mental health in the Brazilian Family Health Strategy. This was an evaluative, qualitative study guided by the Fourth Generation Evaluation framework, developed in a Family Health Strategy unit in a municipality of the state of Rio Grande do Sul. A total of 39 subjects (10 patients, 10 family members and 19 employees) were interviewed. As observed, intersectoral partnerships for mental healthcare are important, as they allow for greater freedom of patients with psychological distress. Among these, the partnership with the resident association and between the Family Health Strategy and the Federal University of Rio Grande do Sul stand out. Despite the difficulties, the consolidation of inclusive projects through an intersectoral approach is emerging as a new way to construct a healthcare agenda that is linked to the needs of the territory, and driven by the premises of the Brazilian Unified Health System.
\end{abstract}

DESCRIPTORS: Mental health. Nursing. Family health.

\section{AVALIAÇÃO DAS PARCERIAS INTERSETORIAIS EM SAÚDE MENTAL NA ESTRATÉGIA SAÚDE DA FAMÍLIA}

RESUMO: Este estudo objetivou avaliar as parcerias intersetoriais em saúde mental na Estratégia Saúde da Família. Estudo avaliativo, qualitativo, orientado pela Avaliação de Quarta Geração e aplicado em uma Estratégia Saúde da Família de um município do Estado do Rio Grande do Sul. Foram entrevistados 39 sujeitos (10 usuários, 10 familiares e 19 trabalhadores). Identificou-se que as parcerias intersetoriais são importantes na saúde mental por permitir o cuidado em liberdade às pessoas com sofrimento psíquico. Destacouse, entre elas, a parceria com a associação dos moradores e a parceria entre a Estratégia Saúde da Família e a Universidade Federal do Rio Grande do Sul. Apesar das dificuldades, considerou-se que a consolidação de projetos inclusivos, a partir de uma abordagem intersetorial, desponta como um novo caminho à construção de uma agenda em saúde, que seja atrelada às necessidades do território e orientada pelas premissas do Sistema Único de Saúde.

DESCRITORES: Saúde mental. Enfermagem. Saúde da família.

\section{EVALUACIÓN DE LAS ASOCIACIONES INTERSECTORIALES EN SALUD MENTAL EN LA ESTRATEGIA SALUD DE LA FAMILIA}

\begin{abstract}
RESUMEN: Se objetivó evaluar las asociaciones intersectoriales en salud mental en la Estrategia Salud de la Familia. Estudio evaluativo, cualitativo, orientado por el referencial de la Evaluación de Cuarta Generación. Fue aplicado en una Estrategia Salud de la Familia de una ciudad del Estado del Rio Grande do Sul. Fueron entrevistados 39 personas (10 usuarios, 10 familiares de usuarios y 19 trabajadores). Se identificó que las asociaciones intersectoriales son importantes en salud mental por ayudar en el cuidado en libertad de las personas con sufrimiento psíquico. Se tornó importante la participación de la asociación de los vecinos y también la asociación entre la Estrategia Salud de la Familia y la Universidad. Se destacó que la consolidación de proyectos inclusivos intersectoriales se desnuda como un nuevo camino hacia la construcción de una agenda vinculada a las necesidades del territorio y orientada por las premisas del Sistema Único de Salud.
\end{abstract}

DESCRIPTORES: Salud mental. Enfermería. Salud de la familia. 


\section{INTRODUCTION}

Psychiatric reform contributes to the intense debate over knowledge and practice in the field of mental health. Causing a reorientation of the care model, the reform has been providing the incorporation of new possibilities for interaction and inclusion of people with psychological distress.

Indeed, the psychiatric reform is a movement and a process; a long path by which we transition and question ourselves. The transformations that accompany it can be felt in the context of public health, because they reflect changes in the thinking and feeling of society as a whole. In particular, the changes were built with mental health professionals, who were also impelled to seek humanized care, and the freedom of the "insane" individual as the beginning, middle and end of care, as for centuries, this individual was left inside isolating walls that were aseptic to the eyes of the world. In this sense, the reform requires that the difference be seen as part of us, and for this purpose, we must seek possible strategies for promoting health and life in any and every social space. ${ }^{1}$

Among the various strategies that can consider the complex dimensions of an individual in psychological distress, mental health policies must target the expansion of the healthcare axis, rather than its reduction. In this sense, intersectoriality stands out as a strategy to articulate services, people and policies.

Intersectoriality may be understood as a complex policy with the aim to overcome the fragmentation of various areas of social work, and the challenge to articulate sectors of society to improve healthcare conditions. ${ }^{2}$ As a management practice, intersectoriality permits the establishment of shared dialogue between institutions, governments and people, acting in the formulation of public policies that can have a positive impact on the health of the population.

The restructuring of healthcare actions permeates the understanding of the complex nuances surrounding it. Understanding this reality requires complementary and interactive intersectoral action and transdisciplinary partnership. Thus, healthcare workers will be closer to the community, in order to confront their problems together. ${ }^{3}$

Strengthening intersectoral partnerships has been the focus of recent national conferences on mental health, especially the 4th meeting in 2010. ${ }^{2}$ The final report from this conference notes that investment is needed in the development of intersectoral activities for education, social welfare, justice and projects for social cooperation and productive inclusion, adhering to criteria of territoriality and regionalization, through dialogue between mental health teams and those who work in other sectors.

Incorporating intersectoriality into public policy brought the articulation of distinct technical knowledge, which provided gains to the population. At the same time, one must understand that sectoral policies (such as healthcare) do not solve everything, and communication is needed to show what they can and cannot offer. Therefore, it should be understood as a rational management strategy in the process of an overall project to overcome the fragmentation of services, especially in face of the localist and clientelist culture of public administration. ${ }^{4}$

In the context of mental health, in light of the change in the psychiatric care model, the patient's return to the environment in which they live, i.e. the territory, is recommended. A territory that is dynamic, where life is created and recreated, where social brands result from singular forms of social relationship. Care in this territory involves being attentive to human singularities, but understanding that it is necessary to trigger and activate other resources and processes to attend to these singularities. ${ }^{5}$

In this sense, the construction of inclusion projects that incorporate partnerships with government resources and the local community can help reframe "insanity" in the social and cultural imagination. Yet, these projects should not fall into the sterile utopia that suffering is a natural event that limits the potential of the other. It is an ethicalaesthetic challenge to articulate services, form networks, bring people and desires together, in a permanent confrontation with the "unknown," the other who suffers and reacts to their suffering in multiple ways, and us, who view the other and their reactions in multiple ways as well. ${ }^{6}$

In this sense, intersectoriality emerges as a principle that can include social movements and stimulate social control, creating new arrangements for funding and sustainability of social inclusion projects (housing, work, income, culture, living, social security, socialization, accessibility, transportation and education), in view of the fulfillment of comprehensive care, equity of care and deinstitutionalization in mental health. ${ }^{2}$

It is believed that intersectoral partnerships are necessary to consolidate the Brazilian psychi- 
atric reform, because the needs of individuals with mental disorders transcend the purely biomedical, and instead span into other dimensions such as access to education, employment, work, housing, safety, leisure, culture, food and life with freedom in society, among others. Therefore, mental healthcare in the territory requires actions based especially on the guideline of comprehensiveness from healthcare professionals in general, as these actions must be eminently patient-centered (in addition to their demands, meeting their needs and seeking to materialize their life projects).

Among the mental healthcare resources that use the space of the territory as a therapeutic medium, primary care, especially through the national Family Health Strategy (FHS), is very important, because the privileged habitat for the treatment of people with mental illness, drug users, victims of violence and those who live with some type of suffering is the neighborhood, family and community, in addition to the health care units in these territories. ${ }^{6}$

Bringing together mental healthcare and the FHS allows for contact and embracement of psychological distress, with different responses from those guided by the biomedical model, whose intervention is focused on the disease. The challenge that arises is how to break with the linear vision of healthcare actions, and embrace a pluralistic range of other professionals for a clinical practice that demands individualization of the subject so that their subjectivity is heard. ${ }^{4}$

Given the aforementioned, and believing in the potential of the FHS as a mental healthcare resource, the aim of this study was to evaluate intersectoral partnerships in mental health in the context of the FHS. We understand that the study can contribute to reflection by healthcare professionals of the FHS and matrix teams about the organization and practice of mental healthcare developed in the territory, and may assist in the consolidation of mental healthcare in the FHS.

\section{METHODOLOGY}

This study is an excerpt from "Avaliação da Saúde Mental na Estratégia Saúde da Família (MENTALESF)", a case study developed in a FHS in the municipality of Porto Alegre, state of Rio Grande do Sul. The Fourth Generation Evaluation ${ }^{7}$ was used as the theoretical and methodological framework of this study, in which the central focus of the evaluation process was to understand the daily service, its dynamics, the way in which the subjects interact, and the meaning they build in relation to their own practice. ${ }^{7}$

The FHS unit studied assists 1,431 families, with two Family Health teams. The region is divided into eight microregions, covering a territory with approximately six thousand people. Each microregion is the responsibility of one community health agent. Each team is composed of one resident physician in Family Health, one nurse, two nursing technicians and four community health agents. The service also has a general assistant.

There are two schools in the community and a building of the community residents' association, where some activities are developed in partnership with the FHS unit.

Study participants were 39 subjects associated with the Family Health Strategy unit of a municipality of Rio Grande do Sul. Of the three interest groups, 10 patients, 10 family members of patients and 19 healthcare professionals (including 16 FHS workers and three from the mental health team) took part in the study. These subjects were chosen as they are believed to be the main protagonists of mental health in the service studied. Professionals from different categories were included, such as nurses, physicians, nursing technicians, community health agents, social workers and psychologists.

This study addresses results found regarding intersectoral partnerships in mental healthcare in the FHS. For this purpose, data obtained from interviews with the three interest groups (patients, professionals and family members) were used.

The team members were identified with the letter $\mathrm{T}$, followed by the order in which they were interviewed, for instance: T3, T10. Patients were identified with the letter $\mathrm{P}$ and family members with the letter $\mathrm{F}$.

The interviews were conducted with the application of the hermeneutic dialectic circle. It is hermeneutic because it is interpretive, and dialectical because it provides the comparison and contrast of divergent views, aiming at achieving a high level of synthesis. ${ }^{7}$ The guiding and triggering theme of the circle was "Tell me about mental healthcare in the FHS unit".

In this sense, the initial respondent $\mathrm{R}_{1}$ participated in an open interview to determine an initial structure in relation to the research focus. The respondent was questioned and asked to construct, describe and comment. At the end of the 
interview, the respondent was asked to indicate another respondent, who was named $\mathrm{R}_{2}$.

The central themes, concepts, ideas, values, concerns and questions proposed by $R_{1}$ were analyzed by the researcher, who formulated a construction designated $\mathrm{C}_{1}$. The second respondent $\left(R_{2}\right)$ was then interviewed, and if some construction broached by $R_{1}$ was not covered by $R_{2}$ he/she was asked to comment on it. The interview with $R_{2}$ produced information from $R_{2}$ and a review of the construction of $R_{1}$. The researcher concluded the second analysis resulting in $\mathrm{C}_{2}$, a more sophisticated and informative construction, and so on until the end of data collection.

The method used requires collection and analysis of data as parallel processes, one driving the other, based on the Constant Comparative Method. $^{7}$

After collecting data and organizing the constructions of each group, the authors developed the negotiation stage, in which all the respondents were brought together and presented with the interim results of the data analysis, so they could have complete access to all the information and the opportunity to either modify it or affirm its credibility. ${ }^{7}$

From the negotiation proceeded the final stage of data analysis, in which the issues raised were regrouped, allowing the construction of markers. Markers are a given category which is abstracted from empirical data, and which has the explanatory power to indicate a specific evaluation parameter. $^{8}$

The results of this paper were organized from the outer marker "intersectoriality," to which questions regarding the mental healthcare network from the FHS converge. Among the points raised by the respondents, it is worth highlighting the residents' association and the partnership between the Federal University of Rio Grande do Sul (UFRGS) and the FHS unit studied, as proposals for mental healthcare, focused on intersectoriality.

The research proposal was approved by the Research Ethics Committee of the City of Porto Alegre, through protocol no. 001.056577.08.7/2008, and all subjects involved signed a Term of Free and Informed Consent, as per resolution 196/1996. ${ }^{9}$

\section{RESULTS AND DISCUSSION}

In the population studied, there are important links between the FHS and other social resources, especially the residents' association.
In addition, the FHS has a partnership with the UFRGS, through internships in the area of mental healthcare and extension activities, which count on the participation of scholars from the school of nursing.

The patients and their families emphasize the interest in strengthening intersectoral partnerships. However, this is being gradually absorbed by the lack of encouragement to participate, especially in relation to participation in the residents' association:

if you ask, if you try with the residents' association here in the region, and the high school, people are willing to help. The staff from the health clinic, they are always very active, diverging a little from medical health, because health is not just made of a doctor. Health also involves the day-by-day, teaching us to live well, a cleaning plan, the environment, water, hygiene care, a lot of things (P5).

our association is falling [...] Sometimes we call on the Centro de Tradições Gaúchas, but there's also an entire process involved, and that whole thing, so there's no physical space, to do any kind of activity, so there's no miracle [...] (P5).

there's the association, which is always empty, no one uses it. (F4).

The residents' association was founded in 1972, and the local health board was created along with the FHS of Pitoresca in 2004..$^{10-11}$ Data collection had the participation of five board members, all of which are patients of the FHS.

The residents' association can function as a powerful mechanism to encourage the participation of the population in decision-making and the construction of a new agenda for healthcare. However, this is only possible when there is strong community mobilization. The residents' association, as demonstrated by P5 and F4, seems to have increasingly fewer members, which puts the consolidation of projects that invest in the quality of life of the people in that territory at risk.

Popular participation is a tool that helps to strengthen the intersectoral approach to healthcare, as it helps service professionals to discover allies in the community in the defense of better working conditions, and to ensure transformative processes, especially in locations that suffer from instabilities generated by political transition. ${ }^{12}$

Therefore, projects that receive contributions from the local community tend to be more effective and generate positive results for people. The frequent proposals to establish local management 
councils that work to maintain social control of healthcare are noteworthy; however, these initiatives still suffer from significant limitations, such as a degree of institutionalization and doubts as for their real power to intervene in local decisions. ${ }^{12}$

Social control in the FHS is a device for the inclusion of patients in psychological distress, mainly because it qualifies actions in mental healthcare in the context of primary care, and enhances spaces of citizenship. In this sense, it is understood that the active involvement of FHS professionals is a political commitment to the community, in an attempt to avoid empty meetings and to strengthen the social control of healthcare in the territory.

It is noteworthy that perhaps one of the greatest contributions to the assessment of mental health services in the FHS is the partnership with UFRGS and the health service studied, through internships and extension activities.

In the undergraduate nursing course, through the Mental Health Nursing II program, offered in the 5th semester, students come into contact with the reality of individuals in psychological distress, and consider the different dimensions of this distress (social, economic, political and cultural).

The course no longer develops practical work in the asylum, since it is not considered a resource that promotes integration, inclusion and independence for people with mental disorders, in which the view shifts from the subject to the disease only, depriving the patient of autonomy, citizenship and the right to come and go. Thus, the course opts to encourage the student's contact with the extra-hospital network, such as the Family Health Strategy, Psychosocial Care Centers and inpatient psychiatric units in general hospitals.

In the activities in the community, it is necessary to emphasize the importance of the student to experience the changes in public policies for mental healthcare. In this context, the student experiences mental healthcare from the concepts of sensitive listening, acceptance, bonds, integrity, accountability, planning and teamwork. The goal is that the student can view patients in their full subjectivity, concerned about their daily life, not just the occasional portion of burdens of the disease. This extends the view to the family of this individual and the entire network of relationships surrounding them.

In the undergraduate internships, one of the activities in the territory is the home visit, under- taken in partnership with the FHS team, as shown by the following statements:

\section{[...] when Professor X came with the internship} students, this was a time that raised my self-esteem. I was miserable, lousy [...] I was drowning myself in drinking [...] they [...] lifted me up [...] gave me strength, gave me morale [...] (P3).

[...] my husband died, and I had serious anxiety issues, you know? They referred me, brought me, a team from UFRGS also came here so we could talk...I interacted with them, and they also interacted with me, a lot, you know? (P5).

[...] I find it very interesting, it is support, I think it is mutual. It is something that gives us a little time, that sometimes we do not have to make some visits and discuss some cases [...] even for the doctors giving this support, in addition to being a training for them, when they come here, it's interesting because there's always something new. They capture, observe the evolution of the case in the patient [...]. So all of this support from the School of Nursing is important, because sometimes they bring some new information [...] since I have been here, they have just brought benefits (T3).

P3 is a patient who suffered greatly from the loss of his wife two years ago. He suffered silently for some time, and developed severe depression along with a regular drinking habit, rarely leaving his home. With the home visits, P3 found space to vent, talk about his problems and expectations for the future, and his self-esteem thus improved.

P5, who also experienced the death of her husband, developed an anxiety disorder. As she reported above, during the visits from the students and the FHS staff, her anxiety decreased because people were available to talk, interact, and ease her mental suffering.

T3 believes that incorporating home visits offered by the School of Nursing into the daily work process of the FHS helps to know the territory better by mapping cases and oftentimes bringing new information for the team to discuss and when appropriate, intervene.

The importance of the home visits as a space for exchange and embracement is perceived in the statements. The home visits allow for strengthening of dialogue, careful listening to people's problems, and also facilitates approximation of the service to the reality of the patients.

In addition to undergraduate activities, the School of Nursing develops extension activities in the community, including during the non-teaching period. Among them, the "Evolution Group" 
stands out, composed of patients with some kind of psychological suffering and their family members. The Evolution Group is coordinated by one of the professors, who supervises the internships.

The families and the staff consider the "Evolution Group" to be an important tool for mental health care in the territory, as confirmed in the following statements:

[...] I think they coexist with each other, with you [nursing students from UFRGS], there are other people there [...] mainly for you who come, 'oh is X [nursing professor from UFRGS] coming?' It is a concern for them, knowing that on such day, because they know exactly which day [mental health group] (F1).

[...] the mental health group, which is the Evolution [group]. I've attended before [...]. They talk and I like it a lot. And it is very important, because it's not just for him [patient], it is also for the caregiver [...]. And it is also good for students who are coming in, that they get familiar with it, too (T10).

[...] so this group is really cool because they get a very good result, very interesting, they want to know when the next one will be, they don't want to stop, they want to continue (T3).

As observed, while the home visits have provided opportunities for subjects to meet the reality of the suffering of patients, in which respect and coexistence with differences have been the greatest focus, the "Evolution Group" serves as a chance for coexistence and sociability, as well as being a space for professional training of undergraduate nursing students, along the lines of the psychiatric reform.

Traditionally, the locus of the internships has been the hospital, which is the headquarters of specialized care and has therapeutic methods focused on advanced technology. With this, the student can be swayed to early specialization in their career, and have a distorted view of the healthcare network itself, centered in the hospital. ${ }^{13}$

Inserting students whose professions are not established in the health services into the networks may increase the possibility of care in the services, as well as reorganize them. In other words, the presence of the university can mobilize the creation of new spaces of intervention in services, such as the proposition of groups, the creation of educational materials, and participation in local management instances, among others. ${ }^{14}$

In this sense, professional training experiences have shown that when the education space is modified, i.e. no longer predominantly around the bed, but in the space of the territory, this helps students to develop broader, more general skills that are relevant to the social reality of users. ${ }^{15}$

It is understandable that the partnership established between the FHS and the university allows for mutual growth and development of their basic prerogatives, namely, while the first has the primary objective to operationalize health care (prevention of diseases, recovery and health promotion for individuals, families and the community), the second seeks, among other things, to train professionals and researchers to meet those needs.

This means that learning spaces should be places for the construction of knowledge and experiences, and development of attitudes that critically produce forms of working in healthcare and relating to patients. That means that the courses should incorporate internships in various sectors, in addition to the health area, providing opportunities for students to exercise negotiation with other instances and become familiar with other spaces, such as non-governmental organizations, schools, boards of health, public squares, community organizations, other municipal departments, etc. This incentive can generate social commitment and help to strengthen the premises of the Brazilian Unified Health System. ${ }^{14}$

In the social reality studied, it is perceived that the university has contributed to this training, as this intersectoral articulation with the FHS is enabling students to exercise broader actions and reflections about this same reality. Thus, although the university still needs to get out of "its walls" more often, strategies like these have made it possible to break with the traditional model of internships in the mental healthcare field, still focused on hospitals.

This is intended to lead the university to its institutionalization, ${ }^{15}$ that is, faced with achievements in the political field, organization of services and health practices, rethink its commitment and transformative role in society. Regarding mental health training, universities should be attentive to respond to the interests of patients and their families, defended both in national conferences on mental health, as well as the movements for health and psychiatric reform.

With regard to services, it is worth remembering that the proposal for territorialization, which broke with the medical- and hospital-centric paradigm, brought to the fore the importance of re-discussing and tackling regional problems of 
the population. In the case of mental health, these problems are often related to individual or collective demands, often pressuring health teams to always do differently. It is to say that this "doing differently" is not just about seeing the health service as a "place that treats" the community; it should provide basic care (medication, guidance on leisure, diet, etc.). It is to view the service as a "place that cares," that is committed to the other, that knows their reality and understands their limitations. ${ }^{16}$

A "new service" that is accessible and committed. A service that is sensitive to the most intimate issues that often disrupt the daily lives of local residents. Forming opinions, which capitalizes on collective efforts around a single project and is concerned with negotiation, contractuality and mutual respect. A work process that values life experience and exchange is one that changes the way teams think and act, and is increasingly focused on the needs of patients. ${ }^{17}$

It is to say that healthcare services should offer spaces that share and welcome the other. It is necessary to be aware of the problems brought by people, because no individual seeks a healthcare service without a need. The service must be a conductor of new capabilities and articulate with other resources provided in the territory, so it is possible to construct life plans that are inclusive, develop autonomy, respect the other, provide freedom and the exercise of their citizenship status. ${ }^{18-19}$

Therefore, it is understood that the partnership between the FHS and UFRGS enables rethinking care of individuals with mental disorders in the community, being a genuine possibility for establishing exchanges and reciprocity, compatible with the intersectoral approach to see healthcare in daily life. According to T13, this is materialized in the home visit, the Evolution Group and the matrix. According to statements by F8, this alone is not enough, because there are other sectors that should be involved:

[...] I think that together, the work of the matrix, the nursing team at UFRGS and the Evolution Group are resources that surely contribute. In order to be able to equip the professional to know that they have more to tell. Not because it's beyond what we were trained for, I think it's because we have the possibility to dialogue with other fronts (T13).

[...] I think general knowledge, because public health, as I said, is a whole. I often see that we are [...] hanging in the wind, and this is not the case. I think an entire work around education needs to be done, and this must involve not only the post. Comprehensive work with all branches of the county government would have to be done, to work on the environment and education as a whole. It's missing, the community needs it, it responds, it is responsive, because when I came here, I did a job like that on the environment and received responses, a lot of resistance, but at the same time it was very rewarding. I did it, it will bring me gratification for the rest of my life. As they say, I did my part, I think the post can do it, but it has to work comprehensively. I think that everything must be integrated, not done alone. One swallow makes summer, but not much (F8).

In the statements of $\mathrm{F} 8$ and $\mathrm{T} 13$ one perceives the need for a concerted effort to build articulated work in healthcare, involving other sectors of civil society and government services with the FHS studied.

Although the family member recognizes that there are difficulties to articulate and develop this intersectoral work, s/he points out that, in addition to being rewarding, such work has concrete results in people's lives. Thus, the challenge remains for FHS professionals and managers that "one swallow makes summer, but not much". Meaning that initiatives, although timid and isolated, are important, however, support is needed (personal and/or institutional) to sustain themselves over time.

In mental health, these strategies outside the walls of the services also have the role to reframe traditional psychiatric care, which is focused on isolation and seclusion. A job which seems fully compatible with the proposal to deconstruct crystallized knowledge on insanity as a disease, as they are devices that accompany patients and provide support to their family, in an attempt to reconnect individuals so that they build new life projects. ${ }^{20}$

The testimonials of users, staff and families also make it possible to assess the potential of these spaces to encourage inclusion. By valuing the presence of the student and the need for partnership with public services, they are indirectly assessing the healthcare work developed by the FHS and the service itself. Their flexibility and interest in learning more about the individuals and their families reaffirm the potential caregiver and the modus operandi of the patient-centered team.

Finally, the partnership between UFRGS, other public sectors and the FHS, even with its difficulties, brings a new dimension to health practices. It values two specific sectors of society (health and education) that remain distant from each other, with very little dialogue. From our 
understanding, a new way of showing that health depends on the efforts of these dialogues, to break with crystallized and fragmentary positions that still insist on following health services.

\section{CONCLUSION}

As observed, the interest groups cited the construction of projects for inclusion, in partnership with the government sectors such as education, culture, environment, security and others. Patients, relatives and staff affirmed that the community studied has important resources to articulate these demands, such as the residents' association and the partnership between the FHS and UFRGS.

Despite the difficulties experienced in everyday life, such as low membership in the residents' association, one of the largest contributions to the strengthening of mental health services in the FHS was the partnership between UFRGS and the FHS, through practical training internships in the area of mental health, developed by the School of Nursing. As one of the internship spaces, FHS provides the opportunity for students and professors to live with the complex demands of mental health planning, discussing cases together and planning care based on these demands.

This is a new way of seeing the complex demands experienced by individuals in psychological distress. If these people were previously excluded from the family and locked in specialized institutions, they can currently socialize with their friends and neighbors, and attend the healthcare services existing in their community. The need for the opportunity to show students these different possibilities of life, through the consolidation of intersectoral partnerships, originates a new path aimed at building an agenda for healthcare that is more tied to the needs of the territory and driven by the SUS premises.

\section{REFERENCES}

1. Lima VBO, Branco Neto JRC. Reforma psiquiátrica e políticas públicas de saúde mental no Brasil: resgate da cidadania das pessoas portadoras de transtornos mentais. Direito \& Política. 2011 Jul-Dez; 1(1):121-31.

2. Ministério da Saúde (BR). Conselho Nacional de Saúde. Relatório final da IV Conferência Nacional de Saúde Mental - Intersetorial. Brasília (DF): MS; 2010.

3. Mielke FB, Cossetin A, Olschowsky A. O conselho local de saúde e a discussão das ações de saúde mental na Estratégia Saúde da Família. Texto Contexto Enferm. 2012 Abr-Jun; 21(2):387-94.
4. Silveira MR. Saúde mental na atenção básica: um diálogo necessário [dissertação]. Belo Horizonte (MG): Universidade Federal de Minas Gerais, Programa de Pós-Graduação em Enfermagem; 2009.

5. Yasui S. A produção do cuidado no território: “há tanta vida lá fora". Textos de apoio do Ministério da Saúde [online]. 2011 [acesso 2012 Jun 30]. Disponível em: http:// portal.saude.gov.br/portal/arquivos/ pdf/cuidadosilvioyasui.pdf

6. Lancetti A, Amarante P. Saúde mental e saúde coletiva. In: Campos GWS, organizador. Tratado de saúde coletiva. São Paulo (SP): Hucitec; 2006. p.615-34.

7. Guba EG, Lincoln YS. Avaliação de quarta geração. Campinas (SP): UNICAMP; 2011.

8. Kantorski LP, Wetzel C, Olschowsky A, Jardim VMR, Bielemann VLM, Schneider JF. Avaliação de quarta geração - contribuições metodológicas para avaliação de serviços de saúde mental. Interface Comunic Saude Educ. 2009 Out-Dez; 13(31):343-55.

9. Ministério da Saúde (BR). Conselho Nacional de Saúde. Comissão Nacional de Ética em Pesquisa. Resolução n. 196 de 10 de outubro de 1996: diretrizes e normas regulamentadoras de pesquisa envolvendo seres humanos - versão 2012. Brasília (DF): MS; 2012.

10. Cossetin A. Controle social na Estratégia Saúde da Família: avaliação participativa das ações em saúde mental [dissertação]. Porto Alegre (RS): Universidade Federal do Rio Grande do Sul, Programa de Pós-Graduação em Enfermagem; 2010.

11. Mielke FB, Olschowsky A. Ações de saúde mental na Estratégia Saúde da Família. Online Braz J Nurs [online]. 2008 [acesso 2012 Abr 16]; 7(2). Disponível em: http://www.objnursing.uff.br/index.php/ nursing/article/view/j.1676-4285.2008.1529/355

12. Feuerwerker LCM, Sena R. A construção de novos modelos acadêmicos, de atenção à saúde e de participação social. In: Ministério da Saúde, organizador. Projeto-piloto do VER-SUS Brasil. Brasília (DF): Ministério da Saúde; 2009. p.149-78.

13. Macedo MCS, Romano RAT, Henriques RLM, Pinheiro R. Cenários de aprendizagem: interseção entre os mundos do trabalho e da formação. In: Pinheiro R, Ceccim RB, Mattos RA, organizadores. Ensinar saúde: a integralidade e o SUS nos cursos de graduação na área de saúde. Rio de Janeiro (RJ): IMS/UERJ; 2005. p.229-50.

14. Pontes ALM, Silva Júnior AG, Pinheiro R. Ensino da saúde e a rede de cuidados nas experiências de ensino-aprendizagem. In: Pinheiro R, Ceccim RB, Mattos RA, organizadores. Ensinar saúde: a integralidade e o SUS nos cursos de graduação na área de saúde. Rio de Janeiro (RJ): IMS/UERJ; 2005. p.251-74.

15. Butti G. Formação e desinstitucionalização em saúde mental. In: Amarante P, Cruz LB, organizadores. Saúde mental, formação e crítica. Rio de Janeiro (RJ): LAPS; 2008. p.51-63. 
16. Yasui S, Costa-Rosa A. A estratégia atenção psicossocial: desafio na prática dos novos dispositivos de saúde mental. Saúde Debate. 2008 Jan-Dez; 32(78/80):27-37.

17. Pinho LB, Hernández AMB, Kantorski LP. Concepção de clientela: análise do discurso da benevolência no contexto da reforma psiquiátrica brasileira. Rev Bras Enferm. 2010 Mai-Jun; 63(3):377-84.

18. Merhy EE. Em busca do tempo perdido: a micropolítica do trabalho vivo em saúde. In: Merhy EE, Onocko R, organizadores. Agir em saúde: um desafio para o público. São Paulo (SP): Hucitec; 2006. p.71-112.

19. Pinho LB. Análise crítico-discursiva da prática de trabalhadores de saúde mental no contexto social da reforma psiquiátrica [tese]. Ribeirão Preto (SP): Universidade de São Paulo. Programa de PósGraduação em Enfermagem Psiquiátrica; 2009.

20. Silva CMC, Teixeira ER, Sabóia VM, Valente GSC. Visita domiciliar na atenção à saúde mental. Cienc Enferm. 2011 Dez; 17(3):125-36. 